\title{
The Effect of Corporate Social Responsibility (CSR) Activities on Consumers Purchase Intention in China: Mediating Role of Consumer Support for Responsible Business
}

\author{
Naveedullah Mulaessa ${ }^{1} \&$ Hong Wang $^{2}$ \\ ${ }^{1}$ School of Economics, Shanghai University, Shanghai, P. R. China \\ Correspondence: Naveedullah Mulaessa, School of Economics, Shanghai University, Shanghai, P. R. China. Tel: \\ 86-131-7494-4040. E-mail: zabinaveed@yahoo.com
}

Received: December 2, 2016

Accepted: December 26, 2016 Online Published: January 16, 2017

doi:10.5539/ijms.v9n1p73

URL: http://dx.doi.org/10.5539/ijms.v9n1p73

\begin{abstract}
Corporate social responsibility (CSR) has demonstrated the positive influence on consumer attitudes and buying behaviors. However the questions worth investigating are "how different CSR types influence consumer purchase intention?" Also, how does firm's overall CSR lead to consumer purchase intention? The purpose of this investigation is to examine the intervening mechanism between CSR and consumer purchase intention. We expect consumer support for responsible business (CSRB) mediates the relationship between CSR and consumer purchase intention. We tested the hypotheses with data from dyad sample of 200 firms' representatives and consumers from apparel industry in China. The result supported the hypothesized relationships between CSR, CSRB, and consumer purchase intention. Findings of this study contribute to the CSR and consumer attitude research. This study also discusses the theoretical and practical implications of the findings.
\end{abstract}

Keywords: corporate social responsibility, consumer support for responsible business, consumer purchase intention, apparel industry, China

\section{Introduction}

Research has revealed that a growing number of consumers encourage and appreciate firm's voluntary activities that positively contribute to society (Lee \& Lee, 2015). In a survey by McKinsey, $89 \%$ of consumers endorse and support companies that balance their obligations to their stakeholders and make contributions to the broader common good (Ramasamy \& Yeung, 2009). Hence, company's voluntary responsibilities such as economic, legal, ethical, and philanthropic towards a society in which it operates have been considered as CSR activities (Carroll, 1979). In other words business companies are not only to make profit but also are responsible to a society within which they operate (Fatma \& Rahman, 2016). Research has revealed that consumer shows positive response towards companies engaged in CSR activities (Parsa, Lord, Putrevu, \& Kreeger, 2015). Therefore, the CSR activities significantly contribute to business companies' image, consumers' purchase intention, and firm's long-term performance (Lee \& Lee, 2015).

Although research studies report a positive influence of firm's CSR activities on consumer's purchase intention and buying decisions (Parsa et al., 2015; Lee \& Lee, 2015), Fatma \& Rahman (2016) consider the findings, relatively, inconclusive. Some studies have opined that consumers are not very much interested in firm's CSR activities because they usually focus more on their self-benefit. Therefore, the CSR activities, relatively, do not relate to company outcomes (Vaaland, Heide, \& Grønhaug, 2008). Furthermore, most of the empirical work on CSR topic has been done in Anglo-Saxon countries, e.g., U.S. and U.K. Research revealed that there have been a few studies of consumer responses to CSR in China (Lee \& Lee, 2015). Therefore, it is important to understand how CSR initiatives were taken in other countries and social contexts, especially in China, influence consumer response (Lee \& Shin, 2010). The important questions that have not been answered in literature explicitly are: To what extent different types of CSR activities influence consumer purchase intention? How does firm's overall CSR lead to consumer purchase intention?

This study examines the relationship between different types of CSR activities and consumer purchase intention. It explores the underlying mechanism between firm's CSR and consumer purchase intention. It investigates CSRB as an underlying mechanism between CSR and consumer purchase intention. This study contributes to the 
CSR literature in several ways. First, it explains the effects of different types of CSR activities on consumer purchase intention. It provides profound commentary relationships between different types of CSR and consumer purchase intention. Second, it uncovers the underlying mechanism between CSR and consumer purchase intention. It illuminates a new way through which CSR influences consumer purchase intention.

\section{Literature Review}

\subsection{Corporate Social Responsibility and Consumer Purchase Intention}

In literature the concept of CSR has been referred to firm's decisions and actions taken beyond the firm's direct economic or technical interest (Davis, 1960; Carroll, 1979). It has also been considered as managerial obligations to take action to protect and improve both the welfare of society as a whole and the interest of the organization. According to the proactive social responsive view the CSR activities emphasize firm's long-term role in a dynamic social system (Mcgee, 1998). Therefore, firms take voluntary actions to become a responsible business entity of a society. These activities not only influence the sale of firm's products and consumers' purchase intention but also employees of the firm. Consumers associate certain expectations with the business entities (firms) that are operating in the society. When business firm's responses, in the form of CSR activities, exceed the consumers' expectations it affects consumer's overall evaluation of firm and its products (David, Kline, \& Dai, 2005).

Research has also revealed that under certain conditions CSR activities have detrimental effects on the consumers' purchase intention (Sen \& Bhattacharya, 2001). Little congruence and fit between firm's product and CSR activities may not lead to positive effect. Most of the studies in the literature reported the positive association of CSR activities and consumer responses and attitudes (Lee \& Shin, 2010; Lee \& Lee, 2015; Fatma \& Rahman, 2016). It is very important to examine the influence of different CSR types on consumer purchase intention. Carroll (1991) suggested four types of social responsibilities that constitute total CSR. Those types of CSR are economic, legal, ethical, and philanthropic. Detail commentary of CSR types visualizes how they are related to CSR and influence consumer purchase intention.

\subsubsection{Economic CSR Activities}

The business organizations are the basic economic units in any society (Carroll, 1979). The fundamental role of the business organization is to produce goods and services that society needs and wants, and to make an acceptable profit in the process. As an economic entity an organization produce goods and services for society, provide jobs, and opportunities for economic activities to the members of society. Through firm's economics activities members of the society earn their living. The Chinese government has established China Social Compliance 9000 for apparel industry that has significantly changed the implications of CSR activities in the industry (Nan \& Heo, 2007). Research has suggested that due to the development of economic conditions and consumer purchasing power, Chinese consumers increasingly demand protection for their resources, communities, and environment (Lee \& Lee, 2015). This forces firms to engage in responsible activities. Therefore, firms take voluntarily positive economics CSR activities to influence members of a society. The members of society establish association and bond with a business organization. Hence, firm's economic CSR activities positive influence members of the society. It also influences consumer purchase intention. Thus, we hypothesize that:

Hypothesis 1: Firm's economic CSR activities positively relate to consumer purchase intention.

\subsubsection{Legal CSR Activities}

Society expects business organizations to comply with the laws and regulations of local government (Carroll, 1991). Organizations that pursue their economics objectives within the framework of local laws positively influence the members of society and also the consumers. Lee \& Lee (2015) found that legal CSR activities positively influence consumer purchase intention. When a firm abides by the local laws and actively participate in activities which promote legal and fair business it sends message to its consumers that it honors the local regulation. Voluntarily abiding and promoting legal issues develop firm's soft image of fair business which ultimately influences consumer intention to purchase firm's products. Thus, based on the above commentary, we hypothesize:

Hypothesis 2: Firm's legal CSR activities positively relate to consumer purchase intention

\subsubsection{Ethical CSR Activities}

Firm's ethical CSR activities or responsibilities embody those standards, norms, or expectations that reflect a concern for what consumers, and society regard as fair, just or in keeping with the respect or protection of 
stakeholders' moral rights (Carroll, 1991). The Chinese society is embedded in Confucius philosophy and values, which sets high standards. Hence, the ethical matters and issues remain an important concern of most of the Chinese consumers (Lee \& Lee, 2015). In the past ethical issues in Chinese apparel industry has been endured such as fake counterfeit products and lower quality than the promised. The firms that overlooked ethical issues lost their business and market share. Therefore, social members and consumers now take seriously the ethical issues. Hence, we expect that firm's CSR activities will positively influence consumer purchase intention. Thus, we posit:

Hypothesis 3: Firm's ethical CSR activities positively relate to consumer purchase intention

\subsubsection{Philanthropic CSR Activities}

Firm's voluntary activities or programs that promote human welfare and goodwill; e.g., contribution of financial resource to community health services, time to art, education, and community well-being, contributes to firm's brand image and business (Carroll, 1991). Greater the firm's contribution to the community the more it improves the quality of life and firms' soft image and higher is the consumers' response to firm's products and services. Research demonstrated that Chinese consumers' value local community development and welfare are more as compared to other issues (Lee \& Lee, 2015). Existing literature endorses the positive association of philanthropic CSR activities and consumer purchase intention. Thus, we hypothesize:

Hypothesis 4: Firm's philanthropic CSR activities positively relate to consumer purchase intention.

Taking all the arguments together and in summary, we propose that firms' CSR activities positively influence the consumer purchase intention. We examine the compound effect of CSR activities on consumer purchase intention.

Hypothesis 5: Firm's overall CSR activities positively relate to consumer purchase intention.

\subsection{Consumer Support for Responsible Business}

The CSRB refers to the extent that consumers encourage and appreciate firm's voluntary actions for social welfare (Maignan, 2001). The research found that 88 percent of consumers are more likely to buy from firms that are socially responsible (Maignan, 2001). The firm's CSR activities positive influence it's responsible actions, such as promoting economic prosperity, compliance with local laws, honoring the community ethical standards, and contributing to social welfare. It will positively influence and attract consumers' support by picturing firm as responsible, which would lead to consumers' purchase intention. We consider that CSRB would work as a conduit between firm's CSR activities and consumer purchase intention. Thus, we hypothesize:

Hypothesis 6: Consumer support for responsible business mediates the relationship of CSR and consumer purchase intention.

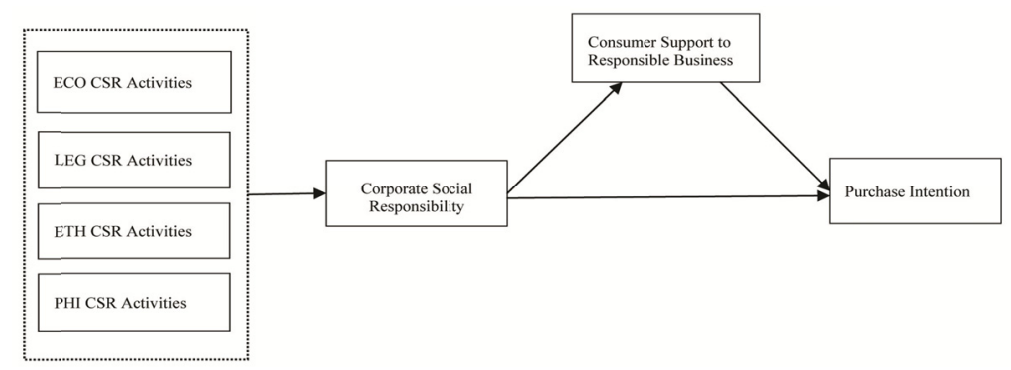

Figure 1. Research framework

\section{Methodology}

\subsection{Sample and Data Collection}

Data was collected from two hundred fifteen firms' representatives and their customers. The firm's representatives were from apparel industry in the People Republic of China. The representatives were well aware of firm's CSR policies and practices. The survey questionnaires were used to collect data from target respondents through personal contacts. Convenience sample strategy was used to collect data. In total, we distributed 430 questionnaires; 215 to the firms' representatives and 215 to their corresponding customers. Two different questionnaires were designed; one for firm's representative to evaluate the firm's CSR activities, and another for 
the customer to evaluate his/her support to responsible business and purchase intention. The consumers were the actual users of firm's products. Research has suggested that consumers' experience significantly influences their attitude, intention, and behavior. Consumers who have actual purchase experience can make purchase decision efficiently (Lee \& Lee, 2015). The questionnaires distributed to them were given serial numbers for matching purpose. The response rate was $93 \%$. Of distributed questionnaires 30 questionnaires were deleted because they were incomplete on major variables or did not match with the corresponding firm. The usable sample was 200 dyad respondents. All the questionnaire items were evaluated on a 4-point Likert scale, ranging from 1 for "strongly disagree" to 4 for "strongly agree". The original survey questionnaire was developed in English. To make it more understandable to the respondent's items were translated into Chinese, translation and back translation was done by bilingual professional (Brislin, 1986). The sample characteristics are presented in Table 1. Of the respondents $51 \%$ were undergraduate, $68 \%$ were male, $52 \%$ have monthly income one thousand dollars, and $43 \%, 41 \%$, and $16 \%$ respondents were between the age of $20-25,26-30,31-35$ respectively.

\subsection{Variables Measurement}

\subsubsection{Corporate Social Responsibility Activities}

The items for four corporate social responsibility activities were taken from Maignan (2001) study. The questionnaire used in this study is provided in Appendix A. The sample items for economic, ethical, legal, and philanthropic responsibilities are "In this company business focus is to maximize profits", "In this company businesses ensure that their employees act within the standards defined by the law", "In this company businesses permit ethical concerns to negatively affect economic performance", "In this company businesses help to solve social problems" respectively. The Cronbach's alpha levels for the economic, legal, ethical, and philanthropic $\mathrm{CSR}$ responsibilities were $\mathrm{ECO}=.89, \mathrm{LEG}=.85, \mathrm{ETH}=.83, \mathrm{PHI}=.82$, respectively. Furthermore, theoretically all the four activities belong to overall firm's CSR and empirically these activities are highly correlated, therefore we calculated Cronbach's alpha for overall CSR which was CSR $=.82$. The Cronbach's alpha values are above the recommended reliability criteria (Churchill \& Peter, 1984). Figure 2 represents the association of economic, ethical, legal, and philanthropic activities with overall CSR.

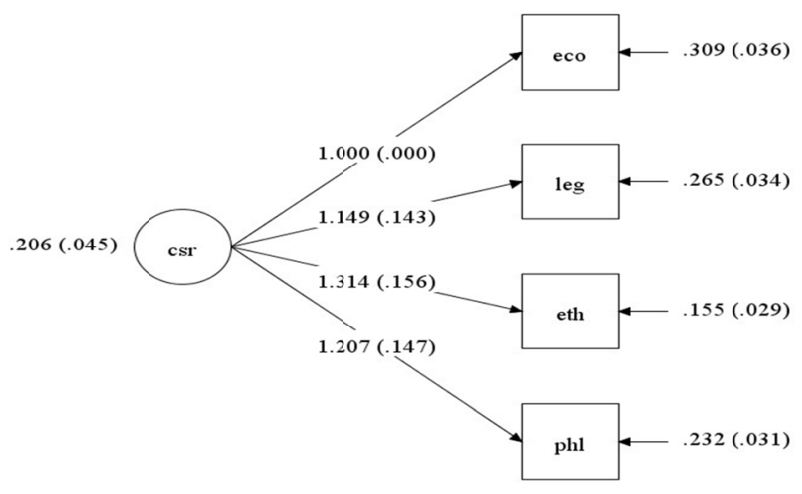

Figure 2. Framework of CSR dimensions

\subsubsection{Consumer's Support for Responsible Business}

The items for consumer's support for responsible business were taken from Maignan (2001) study. The sample item is "I would pay more to buy products from a socially responsible company". The consumers rated their behavior on five points Likert scale $1=$ strongly disagree to $5=$ strongly agree. The Cronbach's alpha value for consumer's support for responsible business was .83 .

\subsubsection{Purchase Intention}

To measure consumer purchase intention 4 items scale was taken from (David et al., 2005). The sample item is "I shall continue to buy products from this company in the next few years". The Cronbach's alpha value for consumer purchase intention was .78 .

\subsubsection{Control Variables}

We used few control variables in this study because those variables may influence the study results systematically. Respondents' age, gender, education, and monthly income were the primary control variables (Sen \& Bhattacharya, 2001). 


\section{Data Analysis and Results}

We used SPSS 22 and MPlus 7 to confirm the reliability and validity of the measures. Following the instruction of Marsh \& Hau (1996), we tested model goodness of fit. A research model is considered good fit if comparative fit index (CFI) and Tucker-Lewis (TLI) values are greater than .90, and root means square error of approximation (RMSEA) is below .08 (Ngo, Foley, \& Loi, 2009). Our study model showed good fit because all the indices values from our study results meet the required standards of valuesRMSEA $=.06, \mathrm{CFI}=.97$, TLI $=.92$. To avoid the possible issue of common method variance (Podsakoff, MacKenzie, Lee, \& Podsakoff, 2003), we collected data from two sources. The firm's CSR activities were evaluated by firm representatives, whereas CSRB and consumer purchase intention were rated by consumers.

Table 1. Respondents' characteristics

\begin{tabular}{lll}
\hline Variables & $\mathbf{n}$ & $\mathbf{\%}$ \\
\hline Education & & \\
\hline Under Graduate & 103 & $51 \%$ \\
Graduate & 97 & $49 \%$ \\
\hline Gender & & \\
\hline Male & 136 & $68 \%$ \\
Female & 64 & $32 \%$ \\
Monthly Income (\$) & & \\
$1-1000$ & 105 & $52 \%$ \\
$1000-2000$ & 95 & $48 \%$ \\
\hline Age & & \\
\hline $20-25$ & 86 & $43 \%$ \\
$26-30$ & 82 & $41 \%$ \\
$31-35$ & 32 & $16 \%$ \\
\hline
\end{tabular}

Note. $\mathrm{N}=200$.

\subsection{Descriptive Statistics}

In Table 2, we present means, standard deviation, and intercorrelations of the variables used in the study. Using bivariate technique in SPSS with Pearson Correlation, we examined the association among study variables. The consumer purchase intention was correlated with CSR activities economic (.50), legal (.57), ethical (.60), and philanthropic (.65) at significance level $p<.01$. The four types of CSR responsibilities were highly correlated; therefore for precise and comprehensive results we aggregated those four dimensions into overall firm's CSR. Therefore, overall CSR was correlated with consumer purchase intention (.19) and with consumer support for responsible business $.17(p<.01)$. Furthermore, the correlation between firm's overall CSR and consumer support for responsible business was .62 $(p<.01)$. It shows a positive association between firm's CSR and consumer support for responsible business. We run variance inflation factor (VIF) test to check the possible issue of multicollinearity among the variables. The results showed that VIF values among independent variables (ECO, LEG, ETH, PHL, CSR) and moderating variable (CSRB) did not exceed the cutoff values of $\beta=2.00$. Therefore, the problem of multicollinearity is not presented in our data.

Table 2. Means, standard deviations, and correlation coefficients of all study variables

\begin{tabular}{|c|c|c|c|c|c|c|c|c|c|c|c|c|c|}
\hline Variable & Mean & SD & 1 & 2 & 3 & 4 & 5 & 6 & 7 & 8 & 9 & 10 & 11 \\
\hline 1. Age & 27.11 & 4.21 & 1 & & & & & & & & & & \\
\hline 2. Gender & 1.32 & 0.45 & -.04 & 1 & & & & & & & & & \\
\hline 3. Education & 2.40 & 0.65 & $.36^{* *}$ & .03 & 1 & & & & & & & & \\
\hline 4. Monthly Income & 4.22 & 1.19 & .03 & .10 & .00 & 1 & & & & & & & \\
\hline 5. ECO Responsibilities & 3.00 & 0.71 & -.05 & .01 & -.03 & .08 & $(.89)$ & & & & & & \\
\hline 6. LEG Responsibilities & 3.23 & 0.73 & -.05 & .00 & .08 & .02 & $.49^{* *}$ & $(.85)$ & & & & & \\
\hline 7. ETH Responsibilities & 3.06 & 0.71 & -.04 & -.03 & -.01 & .02 & $.50^{* *}$ & $.59^{* *}$ & $(.83)$ & & & & \\
\hline 8. PHL Responsibilities & 3.06 & 0.73 & -.01 & .04 & -.01 & -.10 & $.47^{* *}$ & $.51^{* *}$ & $.64^{* *}$ & $(.82)$ & & & \\
\hline 9. CSR & 2.85 & 0.56 & -.06 & -.00 & $-.14^{*}$ & .04 & $.29^{* *}$ & $.28^{* *}$ & $.30^{* *}$ & $.26^{* *}$ & $(.82)$ & & \\
\hline $\begin{array}{l}\text { 10. Cusomer support to } \\
\text { Responsible Business }\end{array}$ & 2.93 & 0.38 & $.14^{*}$ & -.06 & -.01 & -.04 & $.28^{* *}$ & $.31^{* *}$ & $.32^{* *}$ & $.36^{* *}$ & $.17^{* *}$ & $(.83)$ & \\
\hline 11. Consumer Purchase & 3.01 & 0.57 & .03 & -.00 & .04 & -.05 & $.50^{* *}$ & $.57^{* *}$ & $.60^{* *}$ & $.65^{* *}$ & $.19^{* *}$ & $.62^{* *}$ & $(.78)$ \\
\hline
\end{tabular}

Note. ${ }^{*} \mathrm{p}<.05,{ }^{* *} \mathrm{p}<.01,{ }^{* * *} \mathrm{p}<.001, \mathrm{~N}=200$. Cronbach alphas are given in parentheses. $\mathrm{ECO}=$ Economic; $\mathrm{LEG}=\mathrm{Legal}$; ETH = Ethical; $\mathrm{PHL}=$ Philanthropic; $\mathrm{CSR}=$ Corporate Social Responsibility. 


\subsection{Hypothesis Testing}

We performed a linear regression to test the study hypothesis. Table 3 shows the regression results. The control variables age, gender, education, monthly income were not related to consumer purchase intention. In Model 3, CSR activities were positively related to consumer purchase intention. Therefore, the regression coefficient of economic CSR responsibilities with consumer purchase the intention was positive and significant $(\beta=0.14$, $p<.05$ ). Thus regression coefficient is significant at $p<0.05$ level, which supports our hypothesis 1 . The legal CSR responsibilities was positively related with consumer purchase intention $(\beta=0.22, p<.01)$. Hence, regression coefficient is significant at $p<0.05$ level, which supports our hypothesis 2 . The ethical CSR responsibilities was positively related with consumer purchase intention $(\beta=0.17, p<.05)$. It supports our hypothesis 3 because regression coefficient is significant at $p<0.05$ level. The philanthropic CSR responsibilities was positively related with consumer purchase intention $(\beta=0.35, p<.01)$. It endorses our hypothesis 4 because regression coefficient is significant at $p<0.05$ level. The value of R-square $(\beta=0.52, p<.001)$ and $\mathrm{F}$ statistics ( $\mathrm{F}$ $=28.44, p<.001)$ represent substantial level of model good of fit. Hence, our proposed hypothesis regarding types of CSR activities and consumer purchase intention are accepted.

Table 3. The regression results

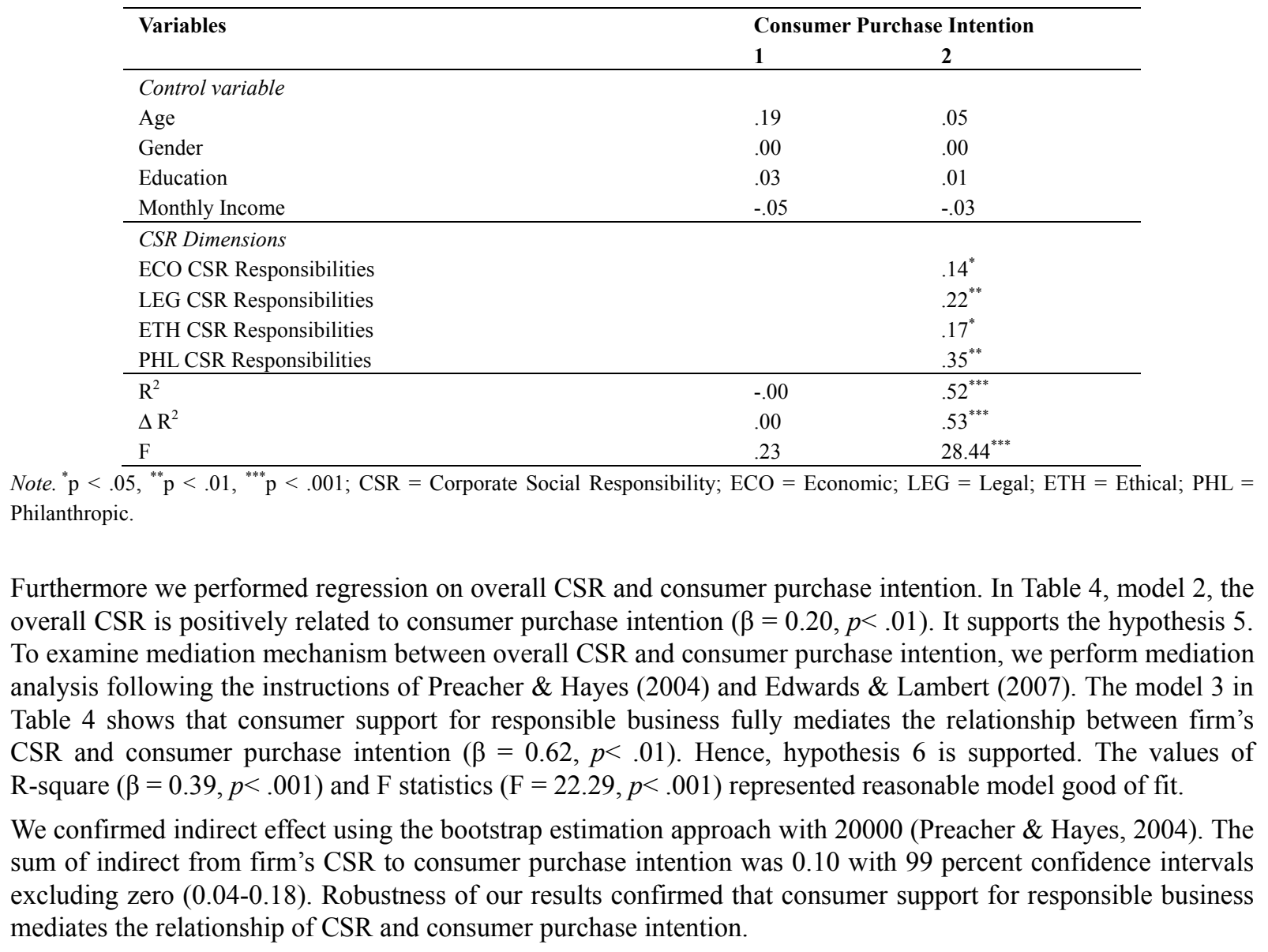


Table 4. The regression results

\begin{tabular}{|c|c|c|c|}
\hline \multirow[t]{2}{*}{ Variables } & \multicolumn{3}{|c|}{ Consumer Purchase Intention } \\
\hline & 1 & 2 & 3 \\
\hline \multicolumn{4}{|l|}{ Control variable } \\
\hline Age & .01 & .02 & -.08 \\
\hline Gender & .00 & .00 & .03 \\
\hline Education & .03 & .06 & .09 \\
\hline Monthly Income & -.05 & -.06 & -.02 \\
\hline \multicolumn{4}{|l|}{ Main Variable } \\
\hline Corporate Social Responsibility & & $.20^{* *}$ & .09 \\
\hline \multicolumn{4}{|l|}{ Mediator } \\
\hline Consumer Support to Responsible Business & & & $.62^{* *}$ \\
\hline $\mathrm{R}^{2}$ & -.01 & $.02^{* *}$ & $.39^{* * *}$ \\
\hline$\Delta \mathrm{R}^{2}$ & .00 & .04 & $.36^{* * *}$ \\
\hline $\mathrm{F}$ & .23 & 1.87 & $22.39^{* * *}$ \\
\hline
\end{tabular}

\section{Finding and Discussion}

This investigation identified and examined the effect of different types of CSR responsibilities on consumer purchase intention in the apparel industry. This study also tested the theoretical model and confirmed that consumer support to responsible business mediates the relationship of CSR and consumer purchase intention. We discuss in detail the study results and implications below.

The economic CSR responsibilities positively influence consumer purchase intention. Relatively, consumers encourage and appreciate business firms that provide necessary goods to the society and earn an acceptable profit in this process (Carroll, 1979). Moreover, business firms that voluntarily obey local rules and regulation attract consumers' attention. Doing this develops an image of the responsible business firm, which most likely influences consumer purchase intention. When firm complies with social ethics it acknowledges the community moral principles. The firm's voluntary activities that promote, adopt, and cherish the social moral philosophy could gain substantial support from the society and community in which it operates. The existing research endorses earlier findings that firm's CSR responsibilities positively influence consumer purchase intention (Lee \& Lee, 2015). The philanthropic activities contribute to social welfare and social good deeds such as firm's voluntary contribution to community welfare, support to children education, health facilities to the local community, and financial support to needy people. These activities attract public attention which contributes to receive public support for business. It confluences positive evaluation and purchase intention.

Another interesting finding of this is that philanthropic and legal responsibilities are more strongly related to consumer purchase intention than economic and ethical responsibilities. Furthermore, legal CSR responsibilities are less significant than philanthropic responsibilities. The business firms in apparel industry should emphasize more on philanthropic CSR activities as compared to economic, ethical, and legal CSR activities. The research endorses earlier findings that influence of philanthropic CSR actives goes beyond the effect of the economic CSR activities (Lee \& Lee, 2015). That is, firm's CSR was more influential when it was supported by the consumers. When consumers support and endorse the firm's CSR activities, their intention to purchase firm's product tends to increase. The implementation of different types of CSR activities has different effects. The firm manager should consider the magnitude of their effect while implementing CSR activities. Market and social context should be considered when designing CSR initiatives.

\subsection{Limitation and Future Directions}

This study is not exempted from a few limitations. First, few aspects of consumers' attitude such as cognitive and affective are not examined. Since all aspects of consumer purchase attitude could not be investigated, a future research should be conducted to examine all the aspects of consumer purchase attitude and cognitive process of purchase intention. Second, we collected dyad sample from apparel industry which may influence generalizability of results. A cluster of consumers' purchase intention could enhance generalization of our findings. Future investigations should examine a cluster of consumers' purchase intention in different industries. Third, this study used survey questionnaires that represent the perception of consumer and firm's representative subjective psychological understanding. For more meaningful and profound understanding experiments in various contexts could be helpful for future studies. Future research is needed to establish causality between CSR activities and aspects of consumers' attitude. 


\section{Conclusion}

The findings of this investigation present a compelling and comprehensive explanation of the relationship between CSR and consumer purchase intention. It explores meaningful effects of different CSR types on consumer purchase intention. The philanthropic CSR activities demonstrate the stronger influence on consumer purchase intention as compared to other CSR activities. The CSRB is identified as a significant underlying mechanism between CSR and consumer purchase intention. Most importantly, the CSRB significantly mediates the relationship between firm's overall CSR and consumer purchase intention. Finally, this study suggests that the strength of the relationship between different CSR types and consumer purchase intention is different. The mediating mechanism of CSRB illuminates the new way between CSR and consumer purchase intention.

\section{References}

Brislin, R. W. (1986). Cross-Culural Research (pp. 137-164). Beverly Hills, CA: Sage.

Carroll, A. B. (1979). A Three-Dimensional Conceptual Model of Corporate Performance. The Academy of Management Review, 4(4), 497-505. http://doi.org/10.2307/257850

Carroll, A. B. (1991). The pyramid of corporate social responsibility: Toward the moral management of $\begin{array}{lllll}\text { organizational stakeholders. } & \text { Business } & \text { Horizons, } & 34(4), & 39-48 .\end{array}$ http://doi.org/10.1016/0007-6813(91)90005-G

Churchill, G. A., \& Peter, J. P. (1984). Research Design Effects on the Reliability of Rating Scales: A Meta-Analysis. Journal of Marketing Research, 21(4), 360-375. http://doi.org/10.2307/3151463

David, P., Kline, S., \& Dai, Y. (2005). Corporate social Responsibility Practices, Corporate Identity, and Purchase Intention: A Dual-Process Model. Journal of Public Relations Research, 17(3), 291-313. http://doi.org/10.1207/s1532754xjprr1703

Davis, K. (1960). Can Business Afford To Ignore Social Responsibilities? California Management Review, 2(3), 70-76. http://doi.org/10.2307/41166246

Edwards, J. R., \& Lambert, L. S. (2007). Methods for integrating moderation and mediation: a general analytical framework using moderated path analysis. Psychological Methods, 12(1), 1-22. http://doi.org/10.1037/1082-989X.12.1.1

Fatma, M., \& Rahman, Z. (2016). The CSR's influence on customer responses in Indian banking sector. Journal of Retailing and Consumer Services, 29, 49-57. http://doi.org/10.1016/j.jretconser.2015.11.008

Lee, J., \& Lee, Y. (2015). The interactions of CSR, self-congruity and purchase intention among Chinese consumers. Australasian Marketing Journal, 23(1), 19-26. http://doi.org/10.1016/j.ausmj.2015.01.003

Lee, K. H., \& Shin, D. (2010). Consumers' responses to CSR activities: The linkage between increased awareness and purchase intention. Public Relations Review, 36(2), 193-195. http://doi.org/10.1016/j.pubrev.2009.10.014

Maignan, I. (2001). Consumers ' Perceptions of Corporate Social Responsibilities: A Cross-Cultural Comparison. Journal of Business Ethics, 30, 57-72.

Marsh, H., \& Hau, K. (1996). Assessing goodness of fit: Is parsimony always desirable? The Journal of Experimental Education, 64(4), 364-390. Retrieved from http://www.tandfonline.com/doi/abs/10.1080/00220973.1996.10806604

Mcgee, J. (1998). Commentary on "corporate strategies and environmental regulations: An organizing framework" by A. M. Rugman and A. Verbeke. Strategic Management Journal, 19(4), 377-387. http://doi.org/10.2307/3094074

Nan, X., \& Heo, K. (2007). Consumer Responses to Corporate Social Responsibility (CSR) Initiatives: Examining the Role of Brand-Cause Fit in Cause-Related Marketing. Journal of Advertising, 36(2), 63-74. http://doi.org/10.2753/JOA0091-3367360204

Ngo, H. Y., Foley, S., \& Loi, R. (2009). Family friendly work practices, organizational climate, and firm performance: A study of multinational corporations in Hong Kong. Journal of Organizational Behavior, 30(2), 665-680. http://doi.org/10.1002/job

Parsa, H. G., Lord, K. R., Putrevu, S., \& Kreeger, J. (2015). Corporate social and environmental responsibility in services: Will consumers pay for it? Journal of Retailing and Consumer Services, 22, 250-260. http://doi.org/10.1016/j.jretconser.2014.08.006 
Podsakoff, P. M., MacKenzie, S. B., Lee, J. Y., \& Podsakoff, N. P. (2003). Common method biases in behavioral research: a critical review of the literature and recommended remedies. The Journal of Applied Psychology, 88(5), 879-903. http://doi.org/10.1037/0021-9010.88.5.879

Preacher, K. J., \& Hayes, A. F. (2004). SPSS and SAS procedures for estimating indirect effects in simple mediation models. Behavior Research Methods, 36(4), 717-731. http://doi.org/10.3758/BF03206553

Ramasamy, B., \& Yeung, M. (2009). Chinese consumers' perception of corporate social responsibility (CSR). Journal of Business Ethics, 88(SUPPL. 1), 119-132. http://doi.org/10.1007/s10551-008-9825-x

Sen, S., \& Bhattacharya, C. B. (2001). Does Doing Good Always Lead to Doing Better? Consumer Reactions to Corporate Social Responsibility. Journal of Marketing Research, 38(2), 225-243.

Vaaland, T. I., Heide, M., \& Grønhaug, K. (2008). Corporate social responsibility: investigating theory and research in the marketing context. European Journal of Marketing, 42(9/10), 927-953. http://doi.org/10.1108/03090560810891082

\section{Appendix A}

\section{Economic Responsibilities (ECO)}

1. In our company business focus is to maximize profits.

2. In our company businesses control their production costs strictly.

3. Our company plans for their long-term success.

4. Our company always tries to improve economics performance.

\section{Legal Responsibilities (LEG)}

1. Our company ensures that their employees act within the standards defined by the law.

2. Our company refrains from putting aside their contractual obligations.

3. Our company refrains from bending the law even it this helps improve performance.

4. Our company always submits to the principles defined by the regulatory system.

\section{Ethical Responsibilities (EHT)}

1. In our company businesses permit ethical concerns to negatively affect economic performance.

2. In our company businesses ensure that the respect of ethical principles has priority over economic performance.

3. In our company businesses are committed to well-defined ethics principles.

4. In our company businesses avoid compromising ethical standards in order to achieve corporate goals.

\section{Philanthropic Responsibilities (PHI)}

1. In our company businesses help solve social problems.

2. In our company businesses participate in the management of public affairs.

3. In our company businesses allocate some of their resources to philanthropic activities.

4. In our company businesses play a role in our society that goes beyond the mere generation of profit.

\section{Consumer Support of Responsible Business}

1. I would pay more to buy products from a socially responsible company

2. I consider the ethical reputation of businesses when I shop

3. I avoid buying products from companies that have engaged in immoral actions.

4. I would pay more to buy the products of a company that shows caring for the well-being of our society

5. If the price and quality of two products are the same; I would buy from the firm that has a socially responsible reputation.

\section{Consumer Purchase Intention}

1. I shall continue to buy products from this company in the next few years.

2. I would keep being a customer of this company even if another entity offered better rates.

3. I would recommend this company if someone asked my advice

4. I would buy upcoming new products of this company.

\section{Copyrights}

Copyright for this article is retained by the author, with first publication rights granted to the journal.

This is an open-access article distributed under the terms and conditions of the Creative Commons Attribution license (http://creativecommons.org/licenses/by/4.0/). 